\title{
POPULATION STRUCTURE AND SPATIAL DISTRIBUTION OF Bauhinia cheilantha (Bong.) Steud. IN TWO FRAGMENTS AT DIFFERENT REGENERATION STAGES IN THE CAATINGA, IN SERGIPE, BRAZIL ${ }^{1}$
}

\author{
Ana Cecília da Cruz Silva² e Diogo Gallo de Oliveira²
}

\begin{abstract}
This study aimed to analyze the vertical and diameter structure and the spatial distribution pattern of Bauhinia cheilantha in two Caatinga fragments in Sergipe, Brazil, at different regeneration stages. Thirty plots were demarcated in area I (Canindé de São Francisco and Poço Redondo), which has vegetation regeneration, and 25 plots in area II (Porto da Folha) with preserved vegetation, both having $400 \mathrm{~m}^{2}$. All B. cheilantha individuals had their height and circumference (circumference at breast height $>6 \mathrm{~cm}$ ) measured. Possible differences in height and diameter at breast height were tested in the two populations by using Student's T-test. The distribution pattern of species was calculated through Payandeh's index. We sampled 154 B. cheilantha individuals, equivalent to $33.3 \%$ of the plots in area I and in 1,027 individuals in area II, totaling $100 \%$ frequency. Height and the diameter of the two populations were statistically different, where AI achieved all values lower than AII. The spatial distribution pattern of B. cheilantha found in both areas was aggregate, with values of 11.85 and 9.00, respectively. Thus, it became clear that the population in AII is at a more advanced successional status than AI, due to its longer conservation time.
\end{abstract}

Keywords: Aggregation; Population density; Mororó.

\section{ESTRUTURA POPULACIONAL E DISTRIBUIÇÃO ESPACIAL DE Bauhinia cheilantha (Bong.) Steud. EM DOIS FRAGMENTOS EM DIFERENTES ESTÁGIOS DE REGENERAÇÃO NA CAATINGA, EM SERGIPE, BRASIL}

\begin{abstract}
RESUMO - O objetivo deste estudo foi analisar a estrutura vertical e diamétrica e o padrão de distribuição espacial de Bauhinia cheilantha em dois fragmentos de Caatinga em Sergipe, no Brasil, em diferentes estágios de regeneração. Foram demarcadas 30 parcelas na área I (Canindé de São Francisco e Poço Redondo), a qual possui vegetação em regeneração, e 25 parcelas na área II (Porto da Folha), com vegetação conservada, ambas com $400 \mathrm{~m}^{2}$. Todos os indivíduos de B. cheilantha tiveram a altura e a circunferência (circunferência à altura do peito $>6 \mathrm{~cm}$ ) mensuradas. Foram testadas possíveis diferenças na altura e no diâmetro à altura do peito entre as duas populações, por meio do teste T de Student. O padrão de distribuição das espécies foi calculado pelo índice de Payandeh. Foram amostrados 154 indivíduos de B. cheilantha, equivalente a 33,3\% das parcelas na área I e 1.027 indivíduos na área II, perfazendo $100 \%$ de frequência. A altura e diâmetro das duas populações diferiram estatisticamente, já que na AI todos os valores foram mais baixos do que na AII. O padrão de distribuição espacial de B. cheilantha encontrado nas áreas foi do tipo agregado, com valores respectivos de 11,85 e 9,00. Assim, evidencia-se que a população da AII está em estado sucessional mais avançado do que em AI, devido ao seu maior tempo de conservação.
\end{abstract}

Palavras-chave: Agregação; Densidade populacional; Mororó.

\footnotetext{
${ }^{1}$ Recebido em 16.06.2013 aceito para publicação em 25.03.2015

${ }^{2}$ Universidade Federal de Sergipe, Mestrado em Ecologia e Conservação, São Cristóvão, Sergipe, Brasil. E-mail:

<cecilia.bio@bol.com.br>e < diogo_gallo@hotmail.com>.
}

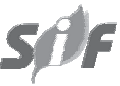

Revista Árvore, Viçosa-MG, v.39, n.3, p.431-437, 2015

http://dx.doi.org/10.1590/0100-67622015000300003 


\section{INTRODUCTION}

Since the early $20^{\text {th }}$ century, most of the Northeastern Brazilian ecosystems are degraded, and their forest remnants consist of secondary formations (GOMES et al., 2006). In Sergipe, Brazil, there is a huge pressure on the original vegetation, since $40 \%$ of the municipalities in this state have more pasture land than native plants (GIULIETTI et al., 2003). So, it is impossible to obtain crucial data (PEREIRA et al., 2001), such as the dynamics and functioning of the biological community, and this situation hinders conservation efforts in many biomes, just as the Caatinga (ALVES et al., 2009).

Even with the advances in biological studies, there is a lack of data on the environmental factors that regulate flora abundance and distribution (GIULIETTI et al., 2003). Clarification of essential information, such as the distribution of species in height and diameter, may be used to make clear the structure and dynamics of plant populations (CALIXTO JÚNIOR et al., 2011; SANTANA et al., 2011). Since even within the same population there is distinction regarding the spatial distribution associated with the size and, abundance classes and/or development stages (SILVA et al., 2009).

Fabaceae is the third largest family of angiosperms, it has about 630 genera and 18,000 species and occurs in a wide range of habitats (JUDD et al., 2009). One of the species belonging to this family is Bauhinia cheilantha (Bong.) Steud., which occurs in Northeastern Brazil and Minas Gerais. It is native to the Caatinga, where it occurs mainly in open formations, on soils poor in nutrients and stony, at altitudes from 350 to $560 \mathrm{~m}$ (QUEIROZ, 2009). It is easily recognized in the field because it is a shrub or small tree with simple, alternate, leaves split at the apex up to the middle (similar to a cow's paw), with white petals and legume-type fruits, linear, flat, and brown.

This species has economic and cultural importance, as its wood has many uses, it is medicinal, forage (LIMA, 1996; ALBUQUERQUE; ANDRADE, 2002; SILVA; CECHINEL FILHO, 2002; AGRA et al., 2007; QUEIROZ, 2009) and it also has the potential to enrich the soil with nitrogen (MAIA, 2004). However, currently, it suffers exploitation pressure (ALCOFORADO-FILHO et al., 2003). Further, it is regarded as a pioneer (MAIA, 2004), so it is suitable to occupy anthropically disturbed areas, as it improves soil structure, fostering ecological succession (SANTANA et al., 2011).

Revista Árvore, Viçosa-MG, v.39, n.3, p.431-437, 2015
This study analyzed the vertical and diameter structure and the spatial distribution pattern of Bauhinia cheilantha individuals in two Caatinga fragments in Sergipe, at different regeneration stages. Specifically, it sought to answer the following questions: i) Is there a difference in height and diameter between individuals of the two populations?; ii) What is the spatial distribution pattern of the two populations of $B$. cheilantha in the areas under study?; and iii) Are the differences found related to the conservation time in these areas?

\section{MATERIALAND METHODS}

The study was conducted in two Caatinga fragments in the high Sergipe state backcountry region, at different regeneration stages. According to Köepen's climatic classification, the climate in the region is Bsh, megathermal semiarid.

Area I (AI; 09³9'S and $\left.37^{\circ} 40^{\prime} \mathrm{W}\right)$ is located in the conservation area "Monumento Natural Grota do Angico", which has a total area of 2,183 ha and it is located in the municipalities of Canindé de São Francisco and Poço Redondo, whose northern boundary is the São Francisco river (SEMARH, 2010). The vegetation cover corresponds to hyperxerophilic Caatinga, undergoing a regeneration process with ecological dominance of Poincianella pyramidalis (Tul.) L.P.Queiroz (SILVA et al., unpublished data). The location has undergone a strong anthropic impact, with a history of fires, removal of timber, and livestock, such as cattle and horses (SILVA et al., 2013). After the creation and deployment of this protected area, in 2007, there was a decrease in these practices (SILVA et al., 2013). The region has an average altitude of $104 \mathrm{~m}$, a mostly wavy soft relief, cut by narrow valleys with dissected slopes (SÁ et al., 2003) and non-calcic brown and litholic soils (JACOMINE et al., 1975). The average annual rainfall precipitation is $600 \mathrm{~mm}$ and the average annual temperature is $26^{\circ} \mathrm{C}$ (SERGIPE, 2011).

Area II (AII; $10^{\circ} 01^{\prime} \mathrm{S}$ e $\left.37^{\circ} 24^{\prime} \mathrm{W}\right)$ is located at "Fazenda São Pedro", which has a total area of 50 ha within Lagoa Grande village, in the municipality of Porto da Folha. The vegetation consists of Caatinga trees, which have been preserved since the 1960s. The average altitude is $168 \mathrm{~m}$, with reliefs dissected on hills and ridges with tabular interfluves and eutrophic litholic neosols, planosols, dystrophic regosols, and eutrophic 
equivalent red-yellow acrisol (SERGIPE, 2011). The average annual rainfall is $548.9 \mathrm{~mm}$ and the average annual temperature is $26.2^{\circ} \mathrm{C}$ (SERGIPE, 2011).

To study the population structure and spatial distribution pattern of Bauhinia cheilantha, we adopted a method of permanent plots (PÉLLICO NETO; BRENA, 1997; RMFC, 2005). In area I, thirty 20 x 20 m plots $\left(400 \mathrm{~m}^{2}\right)$ were demarcated, $289 \mathrm{~m}$ away from each other, and area II had twenty-five $20 \times 20 \mathrm{~m}$ plots, $141 \mathrm{~m}$ away from each other. In each plot, we counted and measured the height and circumference of all living $B$. cheilantha individuals with circumference at breast height $(\mathrm{CBH}$ $-1.30 \mathrm{~m})>6 \mathrm{~cm}(\mathrm{RMFC}, 2005)$.

Phytosociological analysis was performed by using the software Mata Nativa 2 (CIENTEC, 2006). An analysis of the distribution of individuals sampled in relation to height and diameter classes was performed by preparing frequency histograms with an interval of $1 \mathrm{~m}$ and $3 \mathrm{~cm}$, respectively (ALMEIDA NETO et al., 2009; CALIXTO JÚNIOR et al., 2011). In the case of plants with forked stems below the breast height, we measured all branches that were within the inclusion criteria (AMORIM et al.;2005). However, to establish the diameter classes, we considered only the diameter at breast height (DBH - $1.30 \mathrm{~m}$ ) of each individual. Subsequently, we tested possible differences in the structure of the two populations studied by using Student's T-test (ZAR, 1999) for independent samples.

The distribution pattern of the species was calculated through the Payandeh (1970) index. When $P i<1.0$, there is a non-random clustering; when $1.0 \leq P i<1.5$, it indicates a tendency to clustering and when $\mathrm{Pi} \geq$ 1.5 , it indicates clustering or aggregation.

\section{RESULTS}

A total of 1,181 Bauhinia cheilantha individuals were sampled in the two areas, 154 of them were observed in 10 out of the 30 plots in area I, and 1,027 individuals in $100 \%$ of the 25 plots in area II.

In general, the population of $B$. cheilantha may be regarded as medium-sized. The height distribution was unimodal, since there were a higher number of individuals in the intermediate height classes, from 4.0 to $5.9 \mathrm{~m}$ in area I and from 5.0 to $6.9 \mathrm{~m}$ in area II (Figure 1). The minimum heights found in areas I and
II were, respectively, 2.2 and $2.4 \mathrm{~m}$ and the maximum were 7.5 and $10.4 \mathrm{~m}$, with an average height of 4.5 and $5.9 \mathrm{~m}$, statistically different $(\mathrm{t}=-16,15 ; \mathrm{df}=263,47$; $\mathrm{p}<0.0001)$.

The distribution of subjects by diameter class is represented in area I as an inverted and inclined $\mathrm{J}$ shape, concentrated on the first two classes with a smaller diameter, up to $5.9 \mathrm{~cm}$ (Figure 2). In turn, area II showed a unimodal distribution, where the individuals are mainly at the second and third diameter classes, from 3,0 to $8.9 \mathrm{~cm}$ (Figure 2). The average diameter

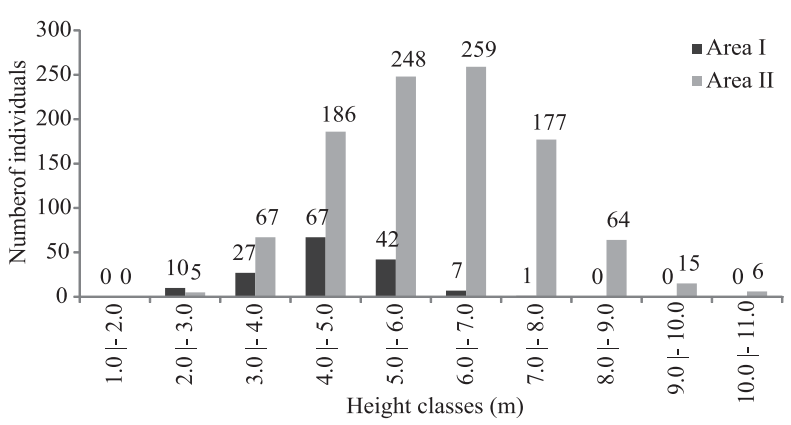

Figure 1 - Distribution of height classes of Bauhinia cheilantha (Bong.) Steud. In two Caatinga fragments in Sergipe, Brazil. Area I: regenerating vegetation $(\mathrm{n}=154)$. Area II: preserved vegetation $(\mathrm{n}=1,027)$.

Figura 1 -Distribuição das classes de altura de Bauhinia cheilantha (Bong.) Steud. em dois fragmentos de Caatinga, em Sergipe. Área I: vegetação em regeneração $(n=154)$. Área II: vegetação conservada $(n=1027)$.

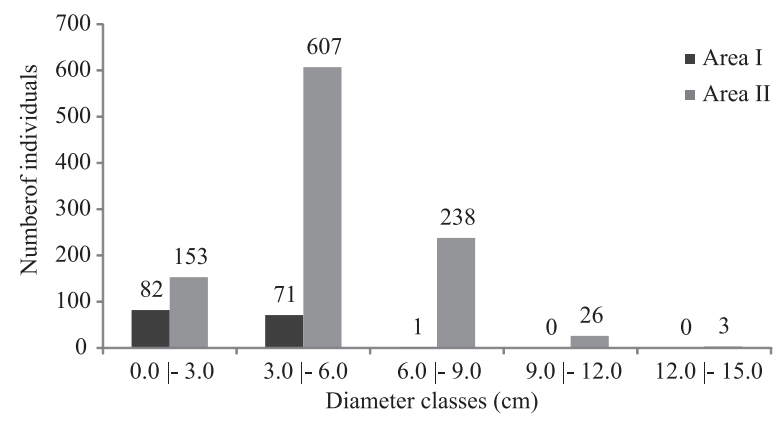

Figure 2-Distribution in diameter classes of Bauhinia cheilantha (Bong.) Steud. two Caatinga fragments in Sergipe, Brazil. Area I: regenerating vegetation $(n=154)$. Area II: preserved vegetation $(\mathrm{n}=1,027)$.

Figura 2 - Distribuição em classes diamétricas de Bauhinia cheilantha (Bong.) Steud. em dois fragmentos de Caatinga, em Sergipe. Área I: vegetação em regeneração $(n=154)$. Área $I I$ : vegetação conservada $(n=1027)$.

Revista Árvore, Viçosa-MG, v.39, n.3, p.431-437, 2015

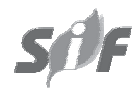


was $3.1 \mathrm{~cm}(\mathrm{AI})$ and $4.9 \mathrm{~cm}(\mathrm{AII})$ and the maximum diameter was $6.9 \mathrm{~cm}(\mathrm{AI})$ and $13.5 \mathrm{~cm}$ (AII), statistically different $(\mathrm{t}=-19,14 ; \mathrm{df}=402,47 ; \mathrm{p}<0.0001)$.

The spatial distribution pattern of $B$. cheilantha found in both areas was aggregate, with respective values of 11.85 (AI) and 9.0 (AII).

\section{DISCUSSION}

The number of cataloged Bauhinia cheilantha individuals in the two areas were higher than those found in other Caatinga areas (PEREIRA et al., 2002; SANTANA; SOUTO, 2006; FABRICANTE; ANDRADE, 2007; RODAL et al., 2008), also in Sergipe (FONSECA, 1991; DÓRIANETO, 2009; FERREIRA, 2011;MACHADO, 2011), which ranged from 3 to 116 individuals, except for two studies conducted in this biome (ALCOFORADOFILHO et al., 2003; BARBOSA et al., 2007), whose values were higher than those in area I.

The absence of individuals in the first height class (up to $2 \mathrm{~m}$ ) in the two areas does not mean that there are no youth individuals and there are recruitment problems for this species. It may be due to the inclusion criteria, i.e. individuals whose $\mathrm{CBH}$ was $>6.1 \mathrm{~cm}$, since in many papers the criterion in this regard is different (SILVA et al., 2012), with a circumference value below that adopted herein. In turn, a big difference between the average and maximum heights indicates that the species is still at a regenerative phase. However, it was found that some $B$. cheilantha individuals have already reached a suitable size in the two areas, since the values were equal to or above the maximum height values observed in various Caatinga locations, ranging from 3.8 to 7.8 (SAMPAIO et al., 1998, FONSECA, 1991; LEMOS; RODAL, 2002; AMORIM et al., 2005).

Regarding the diameter class, only in area I the distribution of individuals achieved the inverted and inclined J-shape, something which characterizes a predominance of young or thin-sized adult individuals. Because most individuals in this location were concentrated on the first class diameter, it is believed that the conservation of this area for a longer time will increase the basal area of the population. The average and maximum diameter values in AI and AII were higher than those found in B. cheilantha individuals in an open and small-sized Caatinga area in Seridó, Rio Grande do Norte, Brazil (AMORIM et al., 2005), something which suggests that both areas are larger than Seridó.
The high concentration of individuals at the smaller height and diameter classes demonstrates that the population is at a regeneration phase (LEHN, 2007). In turn, the population in AII had individuals at higher height and DBH classes than in Al (Figure 1 and 2), confirming the greater local storage times. Populations with higher DBH classes are at a more advanced succession stage than those with lower DBH (ANTONINI; NUNES-FREITAS, 2004). Deforestation, fires, and herbivory by goats change the number, density, and geographical distribution of species in the Caatinga (SAMPAIO et al., 1998; LEAL et al., 2003). In the case of Bauhinia cheilantha, its survival after human disturbance is more affected by the intensity of fires than removal of timber (SAMPAIO et al., 1998).

The spatial distribution values found are far above those observed for other species, such as Mimosa tenuiflora (Willd.) (CALIXTO JÚNIOR et al., 2011) and Poincianella pyramidalis (SANTANA et al., 2011) in Caatinga regeneration areas. Data also indicated that the population in area I is more aggregate than in area II. This fact was also noticed concerning the irregular distribution of species in the sampling units, since in area I the individuals are concentrated in just 10 out of the 30 plots and in area II they are distributed in all plots.

The spatial distribution pattern of woody species in an environment is influenced by biotic and abiotic variables, which may be clustered due to more favorable conditions in a habitat (SILVA et al., 2009). So, changes can be observed in the population structure of a species in the same ecosystem (MIRANDA-MELO et al., 2007). In the case of $B$. cheilantha, aggregation may be related to autochoric dispersion, which facilitates the deposition of seeds close to the mother plant. Checking this pattern is of paramount importance to understand ecological processes and determine the sampling method suitable for restoration of the areas (PALUDO et al., 2011).

\section{CONCLUSION}

The population of Bauhinia cheilantha in area II showed significantly higher height and diameter values than in area I, something which suggests that it at a more advanced successional stage due to longer conservation time. The spatial distribution pattern of the species studied was aggregate in both areas, with greater value and irregularity in the distribution of area I. This pattern may be related to autochoric dispersion and a history of degradation in the areas. 


\section{ACKNOWLEDGEMENTS}

The authors thank to CAPES, for the MS scholarships granted; to the PROAP (Protocol 010386/10-78) and the PROCAD (Protocol 2334/2008-14) for funding; to the SEMARH, for logistics and collection authorization, along with the support of Sidney F. Gouveia, Jefferson S. Mikalauskas, and Bruno B. Souza; to João V. T. Vasconcelos and Manoel M. Nazaré (Mr. Didi), for monitoring in the field; to Mr. Paulo Chave, owner of "Fazenda São Pedro", for providing us with the Caatinga fragment to carry out this study.

\section{REFERENCES}

AGRA, M.F.; BASILIO, I.J.L.D.; BARBOSA, D.A.; BARACHO, G.S.; NURITI, K.; COELHO, V. Sinopse da flora medicinal do Cariri Paraibano. Oecologia Brasiliensis, v.11, n.3, p.323-330, 2007.

ALBUQUERQUE, U.P.; ANDRADE, L.H.C. Conhecimento botânico tradicional e conservação em uma área de Caatinga no estado de Pernambuco, Nordeste do Brasil. Acta

Botanica Brasilica, v.16, n.3, p.273-285, 2002.

ALCOFORADO-FILHO, F.G.; SAMPAIO, E.V.S.B.; RODAL, M.J.N. Florística e fitossociologia de um remanescente de vegetação caducifólia espinhosa arbórea em Caruaru, Pernambuco. Acta

Botanica Brasilica, v. 17, n.2, p.287-303, 2003.

ALMEIDA NETO, J.X.; ANDRADE, A.P.; LACERDA, A.V.; FÉLIX, L.P.; BRUNO,R.L.A. Composição florística, estrutura e análise populacional do feijão-bravo (Capparis flexuosa L.) no semiárido Paraibano, Brasil. Revista Caatinga, v.22, n.4, p.187-194, 2009.

ALVES, J.J.A.; ARAÚJO, M.A.; NASCIMENTO, S.S. Degradação da Caatinga: uma investigação ecogeográfica. Caatinga, v.22, n3, p.126-135, 2009.

AMORIM, I.L.; SAMPAIO, E.V.S.B.; ARAÚJO, E.L. Flora e estrutura da vegetação arbustivoarbórea de uma área de caatinga do Seridó, RN, Brasil. Acta Botanica Brasilica, v.19, n.3, p.615-623, 2005.

ANTONINI, R.D.; NUNES-FREITAS, A.F. Estrutura populacional e distribuição espacial de Miconia prasina D.C. (Melastomataceae) em duas áreas de Floresta Atlântica na Ilha Grande, RJ, Sudeste do Brasil. Acta Botanica Brasilica, v.18, n.3, p.671-676, 2004.

BARBOSA, M.R.V.; LIMA, I.B.; LIMA, J.R.; CUNHA, J.P.; AGRA, M.F.; THOMAS, W.W. Vegetação e flora no Cariri Paraibano. Oecologia Brasileira, v.11, n.3, p.313-322, 2007.

CALIXTO JÚNIOR, J.T.; DRUMOND, M.A.; ALVES JÚNIOR, F.T. Estrutura e distribuição espacial de Mimosa tenuiflora (Willd.) Poir. em dois fragmentos de Caatinga em Pernambuco. Revista Caatinga, v.24, n.2, p.95-100, 2011.

CIENTEC. Mata Nativa 2: Sistema para análise fitossociológica e elaboração de planos de manejo de florestas nativas. Viçosa, MG:

CIENTEC, 2006. 295p.

DÓRIA NETO, A.L. Florística e fitossociologia de uma área de Caatinga em Porto da Folha, Sergipe. Monografia (Graduação em Engenharia Florestal) - Universidade Federal de Sergipe, São Cristóvão, 2009.

FABRICANTE, J.R.; ANDRADE, L.A. Análise estrutural de um remanescente de Caatinga no Seridó Paraibano. Oecologia Brasileira, v.11, n.3, p.341-349, 2007.

FERREIRA, E.V.R. Composição florística, estrutura da comunidade e síndrome de dispersão de um remanescente de Caatinga em Poço Verde - Sergipe. Dissertação (Mestrado em Ecologia e Conservação) - Universidade Federal de Sergipe, São Cristóvão, 2011.

FONSECA, M.R. Análise da vegetação arbustivo-arbórea da caatinga hiperxerófila do noroeste do estado de Sergipe. Tese (Doutorado em Biologia Vegetal) Universidade Estadual de Campinas, Campinas, 1991.

GIULIETTI, A.M.; CASTRO, A.A.J.F.; GAMARRA-ROJAS, C.F.L.; SAMPAIO, E.V.S.B.; VIRGÍNIO, J.F.; QUEIROZ, L.P.; FIGUEIREDO, M.A.; RODAL, M.J.N.; BARBOSA, M.R.V.; HARLEY, R.M. Diagnóstico da vegetação nativa do bioma Caatinga. In: SILVA, J.M.C.;

Revista Árvore, Viçosa-MG, v.39, n.3, p.431-437, 2015 
TABARELLI, M.; FONSECA, M.T.; LINS, L.V. (Org.). Biodiversidade da caatinga: áreas e ações prioritárias para a conservação. Brasília: Ministério do Meio Ambiente, Universidade Federal de Pernambuco. 2003. p.47-90.

GOMES, L.J.; SANTANA, V.; RIBEIRO, G.T. Unidades de Conservação no Estado de Sergipe. Revista da Fapese, v.2, n.1, p.101-112, 2006.

JACOMINE, P. K. T.; MONTENEGREO, J. O.; RIBEIRO, M.T.; FORMIGA, R.A..

\section{Levantamento exploratório-}

reconhecimento de solos do estado de

Sergipe. Recife: Empresa Brasileira de Pesquisa Agropecuária/Superintendência do

Desenvolvimento do Nordeste. 1975. (Boletim técnico, 36; Série Recursos de Solos, 6)

JUDD, W.S.; CAMPBELL, C.S.; KELLOGG, E.A.; STEVENS, P.F.; DONOGHU, M.J. Sistemática vegetal: um enfoque filogenético. André Olmos Simões (trad.). 3.ed. Porto Alegre: Artmed, 2009.

LEAL, I.R., VICENTE, A.; TABARELLI, M. Herbivoria por caprinos na Caatinga da região de Xingó: uma análise preliminar. In: LEAL, I.R.;

TABARELLI, M.; SILVA, J.M.C. (Orgs.).

Ecologia e conservação da Caatinga. Recife: UFPE, 2003.p.695-716.

LEHN, C.R. Estrutura populacional e padrão de distribuição espacial de Cyathea delgadii Sternb. (Cyatheaceae) em uma Floresta Estacional Semidecidual no Brasil Central. Revista Biociências, v.13, n.3-4, p.188-195, 2007.

LEMOS, J.R.; RODAL, M.J.N. Fitossociologia do componente lenhoso de um trecho da vegetação de Caatinga no Parque Nacional Serra da Capivara, Piauí, Brasil. Acta Botanica Brasilica, v. 16, n.1, p.23-41, 2002.

LIMA, J.L.S. Plantas forrageiras das caatingas - uso e potencialidades. PetrolinaPE: Embrapa-CPATSA/PNE/RBG-KEW, 1996.

MACHADO, W.J. Composição florística e estrutura da vegetação em área de Catinga e Brejo de altitude na Serra da Guia, Poço Redondo, Sergipe, Brasil. Dissertação (Mestrado em Ecologia e Conservação) - Universidade Federal de Sergipe, São Cristóvão, 2011.
MAIA, G.N. Caatinga: árvores e arbustos e suas utilidades. São Paulo: D\&Z Computação. 2004.

MIRANDA-MELO, A.A.; MARTINS, F.R.; SANTOS, F.A.M. Estrutura populacional de Xylopia aromatica (Lam.) Mart. e de Roupala montana Aubl. em fragmentos de Cerrado no Estado de São Paulo. Revista Brasileira de Botânica, v.30, n.3, p.501-507, 2007.

PALUDO, G.F.; MANTOVANI, A.; REIS, M.S. Regeneração de uma população natural de Araucaria angustifolia (Araucariaceae).

Revista Árvore, v.35, n.5, p.1107-1119, 2011.

PAYANDEH, B. Comparison of method for assessing spatial distribution of trees. Forest Science, v.16, p.312-317, 1970.

PÉLLICO NETO, S.; BRENA, D.A. Inventário Florestal. Curitiba: Edição dos Autores, 1997.

PEREIRA, I.M.; ANDRADE, L.A.; COSTA, J.R.M.; DIAS, J.M. Regeneração natural em um remanescente de Caatinga sob diferentes níveis de perturbação, no Agreste Paraibano. Acta Botanica Brasilica, v.15, n.3, p.413-426, 2001.

PEREIRA, I.M.; ANDRADE, L.A.; BARBOSA, M.R.V.; SAMPAIO, E.V.S.B. Composição florística e análise fitossociológica do componente arbustivo-arbóreo de um remanescente florestal no agreste paraibano. Acta Botanica Brasilica, v.16, n.3, p. 357-369, 2002.

QUEIROZ, L.P. Leguminosas da caatinga. Feira de Santana: Universidade Estadual de Feira de Santana, 2009.

COMITÊ TÉCNICO CIENTÍFICO DA REDE DE MANEJO FLORESTAL DA CAATINGA - RMFC. Rede de manejo florestal da Caatinga: protocolo de medições de parcelas permanentes. Recife: Associação Plantas do Nordeste, 2005.

RODAL, M.J.N.; MARTINS, F.R.; SAMPAIO, E.V.S.B. Levantamento quantitativo das plantas em trechos de vegetação de Caatinga em Pernambuco. Revista Caatinga, v.21, n.3, p.192-205, 2008.

Revista Árvore, Viçosa-MG, v.39, n.3, p.431-437, 2015 
SÁ, I.B.; RICHÉ, G.R.; FOTIUS, G.A. As paisagens e o processo de degradação do semiárido nordestino. In: SILVA, J.M.C. TABARELLI, M.; FONSECA, M.T.; LINS, L.V. (Orgs.).

Biodiversidade da Caatinga: áreas e ações prioritárias para a conservação. Brasília, DF: Ministério do Meio Ambiente, Universidade Federal de Pernambuco, 2003. p.17-36.

SAMPAIO, E.V.S.B.; ARAÚJO, E.L.; SALCEDO, I.H.; TIESSEN, H. Regeneração da vegetação de caatinga após corte e queima, em Serra Talhada, Pesquisa Agropecuária Brasileira, v.33, n.5, p.621-632, 1998.

SANTANA, J.A.S.; SOUTO, J.S. Diversidade e estrutura fitossociológica da Caatinga na Estação Ecológica do Seridó - RN. Revista de Biologia e Ciências da Terra, v.6, n.2. p.232-242, 2006.

SANTANA, J.A.S.; VIEIRA, F.A.; PACHECO, M.V.; OLIVEIRA, P.R.S. Padrão de distribuição e estrutura diamétrica de Caesalpinia pyramidalis Tul. (Catingueira) na Caatinga do Seridó.

Revista de Biologia e Ciências da Terra, v.11, n.1, p. 116-122, 2011..

\section{SECRETARIA DO MEIO AMBIENTE E DOS} RECURSOS HÍDRICOS - SEMARH. Unidades de Conservação. 2010. [Acessado em 02 de fev. 2013] Dispónivel em: http://

www.semarh.se.gov.br/biodiversidade/modules/ tinyd0/index.php?id=11.
SERGIPE. Secretaria de Estado do Planejamento, da Ciência e da Tecnologia. Atlas digital sobre recursos hídricos Sergipe. Sergipe: SEPLANTEC/SRH, 2011. CD-ROM..

SILVA, A.C.C.; PRATA, A.P.N.; SOUTO, S.L.; MELLO, A.A. Aspectos de ecologia de paisagem e ameaças à biodiversidade em uma Unidade de Conservação na Caatinga em Sergipe. Revista Árvore, v.37, n.3, 2013.

SILVA, K.E.; MARTINS, S.V.; SANTOS, N.R.; RIBEIRO, C.A.A.S. Padrões espaciais de espécies arbóreas tropicais. In: MARTINS, S.V. (Ed.). Ecologia de florestas tropicais do Brasil. Viçosa, MG: Universidade Federal de Viçosa, 2009. p. 216-244.

SILVA, K.L.; CECHINEL FILHO, V. Plantas do gênero Bauhinia: composição química e potencial farmacológico. Química Nova, v. 25, n.3, p.449-454, 2002.

SILVA, S.O.; FERREIRA, R.L.C.; SILVA, J.A.A.; LIRA, M.A.; ALVES JUNIOR, F.T.; CANO, M.O.O.; TORRES, J.E.L. Regeneração natural em um remanescente de Caatinga com diferentes históricos de uso no Agreste Pernambucano. Revista Árvore, v.36, n.3, p.441-450, 2012.

ZAR, J.H. Biostatistical analysis. 4.ed. New Jersey: Prentice Hall, 1999. 